\title{
MINERAL ROYALTIES: HISTORICAL USES AND JUSTIFICATIONS
}

\author{
Jayni Foley Hein* and Caroline Cecot**
}

Governments and private landowners have collected royalties on mineral resources for centuries. When comprehensive measures to account for the environmental externalities of mineral extraction are politically or practically unavailable, federal and state governments may consider adjusting royalty rates as an expedient way to account for these externalities and benefit society. One key policy question that has not received attention, however, is whether a royalty rate can and should be manipulated in this way, assuming statutory discretion to do so. This article fills that gap by evaluating the argument for increasing federal or state fossil fuel royalty rates through historical, theoretical, and practical lenses. To that end, this article in turn considers the meaning of royalties, the economic justifications for royalties, the legislative history of the implementation of federal royalties, and the considerations that private landowners have relied upon in setting royalties. This article concludes that it would be appropriate for governments to adjust mineral royalty rates to account for negative externalities not otherwise addressed by regulation or to otherwise promote public welfare. Such use of royalties is consistent with the historical record. Royalties have been used as pragmatic policy tools from almost their inception, and federal and state governments have often exercised their existing statutory discretion to adjust mineral royalty rates to promote public welfare.

Copyright $(2017$ Jayni Foley Hein \& Caroline Cecot.

* Jayni Foley Hein is the Policy Director at the Institute for Policy Integrity at New York University School of Law and an Adjunct Professor of Law at New York University School of Law.

** Caroline Cecot is an Assistant Professor of Law at Antonin Scalia Law School at George Mason University. The authors wish to thank Richard Revesz, Peter Howard, and Jason Schwartz for their comments. Katherine Rouse and Sara Savarani provided excellent research assistance. This article does not necessarily reflect the views of New York University School of Law or Antonin Scalia Law School. 


\section{INTRODUCTION}

Royalty revenue from coal, oil, and natural gas production on federal and state lands is an important source of U.S. federal and state government funds. The federal government currently collects about $\$ 6.23$ billion in annual payments from federal leases and shares approximately half of these proceeds with the states in which mineral production occurs. ${ }^{1}$ States also collect royalties from mineral resource production on their own lands and use the revenue to fund public education, infrastructure projects, environmental projects, and other useful government spending. ${ }^{2}$ Thus, setting the appropriate royalty rate can have significant implications for public welfare.

Increasingly, scholars and advocates argue that federal royalty rates are set too low, depriving the public of a larger share of revenue that is rightfully theirs by failing to account for the negative externalities of fossil fuel production borne by the public. ${ }^{3}$ Fossil fuel production results in emissions of greenhouse gases and other air pollutants, as well as water pollution, habitat disruption, and other environmental harms. These scholars and advocates argue that federal royalty rates should reflect these societal costs, and devote considerable efforts to calculating the optimal royalty rate to serve

1. 30 U.S.C. $\$ 191(\mathrm{a})-(\mathrm{b})$; see also U.S. OFFICE OF NAT. RES., Interior Department Disburses \$6.23 Billion in FY 2016 Energy Revenues: Federal Revenues Support State, Tribal, National Needs (Nov. 25, 2016), https://www.onrr.gov/pdfdocs/20161125a.pdf. One exception is Alaska, which is entitled to 90 percent of federal royalties for onshore oil, gas, and coal production in the state. 30 U.S.C. $\S 191(a)$.

2. See David Woodgerd \& Bernard F. McCarthy, State School Trust Lands and Oil and Gas Royalty Rates, 3 PUB. LAND L. REV. 119, 130 (1982) (stating that the state of Montana collects royalties from mineral resources to promote public welfare); Headwaters Economics, THE Impact of Federal CoAl Royalty Reform on Prices, Production, and State REVENUE 5, 17 (May 2015), https://headwaterseconomics.org/wp-content/uploads/Report-CoalRoyalty-Reform-Impacts.pdf.

3. See, e.g., Jayni Foley Hein, Priorities for Federal Coal Reform, Inst. for Policy Integrity, NYU School of Law (June 2016), http://policyintegrity.org/files/publications/ Priorities_for_Coal_Reform.pdf (analyzing the federal coal program); Jayni Foley Hein \& Peter Howard, Illuminating the Hidden Costs of Coal, Inst. for Policy Integrity, NYU School of Law (Dec. 2015), http://policyintegrity.org/files/publications/Hidden_Costs_of_Coal.pdf (illustrating that externalities of coal have not been included the federal royalties); Spencer Reeder \& James H. Stock, Federal Coal Leasing Reform Options: Effects on CO2 Emissions and Energy Markets: Executive Summary, VULCAN PHILANTHROPIES 4 (Feb. 2016), http://www.vulcan.com/ MediaLibraries/Vulcan/Documents/FedCoalLeaseModelResults_ExecutiveSummary_Vulcan_F INAL_16Feb2016.pdf; Tom Sanzillo, The Great Giveaway: An Analysis of the Costly Failure of Federal Coal Leasing in the Powder River Basin, InST. FOR ENERGY ECON. \& FIN. ANALYSIS (2012) (estimating that the federal government lost $\$ 28.9$ billion in revenues over thirty years due to Interior's failure to receive fair market value for coal mined in the Powder River Basin, which produces 43 percent of the nation's coal). 
various goals, including accounting for externalities ${ }^{4}$ and ensuring that a "fair market value" is returned to the government. ${ }^{5}$

In the final years of the Obama administration, the Department of Interior ("Interior") took notice of several outdated components of the federal coal program. On January 15, 2016, Interior announced that it would launch a comprehensive review to identify and evaluate potential reforms to the program. This review would analyze issues that include "how to account for the environmental and public health impacts of federal coal production; and how to ensure American taxpayers are earning a fair return for the use of their public resources." Interior released its Scoping Report in January 2017 and committed to further analyzing potential royalty rate increases for federal coal that would account for some of the externality costs of coal production. $^{7}$

On March 28, 2017, President Trump issued an executive order directing the Secretary of the Interior to end the coal review, ${ }^{8}$ and Secretary Ryan Zinke promptly followed suit. ${ }^{9}$ President Trump has repeatedly stated that he would like to bring back coal by eliminating regulations on the industry, many of which reduce externalities associated with generating electricity from coal. ${ }^{10}$ However, President

4. See Hein \& Howard, Illuminating the Hidden Costs of Coal, supra note 3.

5. The White House, OfFice of the President, the ECONOMICS OF COAL LeAsing ON FEDERAL LANDS: ENSURING A FAIR RETURN TO TAXPAYERS (2016), https://obamawhitehouse.archives.gov/sites/default/files/page/files/20160622_cea_coal_leasing.p df\% 22\%22 [hereinafter "CEA Coal Report"].

6. Press Release, U.S. Dep't of the Interior, Office of the Secretary, Secretary Jewell Launches Comprehensive Review of Federal Coal Program (Jan. 15, 2016), https:/www.doi.gov/pressreleases/secretary-jewell-launches-comprehensive-review-federal-coalprogram.

7. U.S. DeP'T of Interior, Federal CoAl Program: Programmatic ENVIRONMENTAL IMPACT STATEMENT - SCOPING REPORT VOL. I, ES-1 (2017), https:/eplanning.blm.gov/epl-front-office/projects/nepa/65353/95059/114965/

CoalPEIS_RptsScoping_Vol1_508.pdf.

8. See The White House, Office of the Press Secretary, Presidential EXECUTIVE ORDER ON PROMOTING ENERGY INDEPENDENCE AND ECONOMIC GROWTH (Mar. 28, 2017), https:/www.whitehouse.gov/the-press-office/2017/03/28/presidential-executive-orderpromoting-energy-independence-and-economi-1 ("The Secretary of the Interior shall take all steps necessary and appropriate to amend or withdraw Secretary's Order 3338 dated January 15, 2016 (Discretionary Programmatic Environmental Impact Statement (PEIS) to Modernize the Federal Coal Program), and to lift any and all moratoria on Federal land coal leasing activities related to Order 3338.").

9. See Dep't of the Interior, Secretarial Order 3348 (Mar. 29, 2017), https://www.eenews.net/assets/2017/03/30/document_gw_01.pdf (revokes the secretaries' order 3338).

10. On March 28, 2017, President Trump, surrounded by energy-industry executives and coal miners, signed an Executive Order designed to back away from Obama-era climate regulations, 
Trump claims to value getting a good deal, and numerous studies show that increasing federal coal royalties can earn more revenue for taxpayers. ${ }^{11}$ As such, increasing a production-based tax in the form of a higher royalty rate may be an attractive way for his administration to account for externalities without regulation, or to achieve other legitimate policy goals, such as earning more revenue for taxpayers. In fact, Secretary Zinke established a federal "Royalty Policy Committee" comprised of representatives of states, energy companies, and tribes, which is tasked with ensuring that "the public receives the full value of the natural resources produced from Federal lands." ${ }^{12}$ It remains to be seen what proposals the committee will put forward.

Many states may also be interested in using royalty rate reform to meet state revenue or other policy goals. Independent studies show that increasing federal royalty rates can provide net revenue increases to both the states in which mineral production occurs and the federal government. ${ }^{13}$ This additional revenue can be directed back to the resource-producing states and communities in which production occurs. Some states may also be interested in royalty rate reform for environmental purposes such as greenhouse gas emission reduction goals, especially as the Trump administration moves away from federal climate change regulation. ${ }^{14}$

Despite statutory discretion to alter royalty rates, as well as momentum during the Obama administration to reevaluate and potentially increase them, one policy question that has not received

including the Clean Power Plan. Trump said, "You know what this says? You're going back to work." Coral Davenport \& Alissa J. Rubin, Trump Signs Executive Order Unwinding Obama Climate Policies, N.Y. Times, Mar. 28, 2017, https://www.nytimes.com/2017/03/28/climate/trumpexecutive-order-climate-change.html; see also Donald Trump's Contract with the American Voter, https://assets.donaldjtrump.com/_landings/contract/O-TRU-102316-Contractv02.pdf ("FIFTH, I will lift the restrictions on the production of $\$ 50$ trillion dollars' worth of jobproducing American energy reserves, including shale, oil, natural gas and clean coal.").

11. See, e.g., CEA Coal Report, supra note 5 (analysis of the federal coal leasing program); Hein \& Howard, Illuminating the Hidden Costs of Coal, supra note 3; Reeder \& Stock, Federal Coal Leasing Reform Options, supra note 3;

12. DeP'T of the Interior, Royalty Policy Committee Charter (Mar. 29, 2017), https:/www.doi.gov/sites/doi.gov/files/uploads/2017_signed_charter_royalty_policy_committee_ 03_29_17.pdf.

13. See, e.g., Mark Haggerty, An Assessment of U.S. Federal Coal Royalties: Current Royalty Structure, Effective Royalty Rates, and Reform Options, 8 HEADWATERS ECON. (2015), http://headwaterseconomics.org/wphw/wp-content/uploads/Report-Coal-Royalty-Valuation.pdf (Demonstrating potential royalty rate increases within the context of coal production).

14. See Brad Plummer, Donald Trump is Preparing to Make Massive Policy Changes at the EPA, VOX (Jan. 23, 2017), http://www.vox.com/energy-and-environment/2017/1/23/14356652/ trump-epa-regulations ("Trump's team will move to tackle many of the existing environmental rules and regulations put in place under Obama”). 
attention in the literature is whether there is some theoretical basis or historical precedent for modifying royalty rates to meet public policy goals. This article fills that gap, evaluating the argument for increasing federal or state fossil fuel royalty rates through historical, theoretical, and practical lenses. To that end, this article in turn considers the historical meaning of royalties, the economic justifications for royalties, the legislative history of the implementation of federal royalties, and considerations that private landowners have relied upon in setting royalties. While royalties typically have a revenue or profitsharing component, a common thread in our research that may be especially relevant to federal and state governments is that royalties have historically been used as policy levers to help set national, state, or private priorities for land, resources, or property use. For example, the United States government has set royalties at specific rates to encourage resource production, encourage westward expansion, and deter socially undesirable behavior. Accordingly, this article concludes that it would be reasonable for federal and state governments to adjust mineral royalty rates to account for negative externalities that are not otherwise addressed by regulation, or to otherwise promote public welfare.

The article begins with a review of the common law origins of royalties for mineral resource extraction. Royalties were paid to the sovereign or to private landowners in order to share the value of the resource and for the privilege of mining on the property. Next, Part II describes the economic theories used as justifications for royalties: the owner's share of differential returns on mines given their superior productivity (economic rent); payments to the owner for minerals removed (user cost); and compensation for negative externalities from the extraction or use of minerals.

In Part III, the article reviews the legislative history of mineral resource extraction law and policy in the United States, with a focus on federal royalties. The federal government has consistently used leasing policies and royalty rates as policy levers to advance the national interest and to compensate the public for the removal of mineral resources. Beginning in the 20th century, legislative history also reveals growing attention to the relationship between fossil fuel royalty rates and externalities. This trend has shown itself through state and federal government revenue sharing arrangements; the Land and Water Conservation Fund, which directs a portion of oil and gas royalty revenue to conservation and environmental mitigation; and recent calls 
for hardrock mining royalty reform on the basis of the externalities associated with such production.

Finally, Part IV of the article briefly examines decisions private parties make when leasing their land to third parties for mineral extraction. Like public royalty rates, private royalty rates and mineral resource leases are influenced by diverse factors, including expected economic rent, characteristics of the resource, competition for the lease, and externalities that may affect the leaseholder, such as noise and pollution. By examining the decisions private parties make to maximize their self-interest, this Article highlights the factors government decision makers should consider when acting in society's best interest.

Taken together, the historical and economic justifications for royalties support federal and state governments exercising their existing statutory discretion to raise mineral resource royalty rates to account for factors such as negative externalities, including those resulting from carbon dioxide and methane emissions. Indeed, exercising this discretion would be an expedient and potentially lucrative way to align natural resource leasing with greenhouse gas reduction goals. This remains a politically viable option even as other mechanisms to address climate change appear infeasible in the current political environment.

\section{The ORIGIN OF Mineral Royalties}

According to some scholars, English common law origins of the word "royalty" and concepts of ownership played a role in the formation of U.S. common law. ${ }^{15}$ As early as 1400 , the term "royalty" was used by the British Crown to describe any "right or privilege retained by the crown." ${ }^{16}$ It became associated with mineral rights in particular by 1580 , when the British Crown retained title to all land and the right to take any gold or silver discovered on land conveyed. ${ }^{17} \mathrm{By}$ 1829 , the term royalty specifically meant a right retained by a landowner under a lease in return for the privilege of working a mine. ${ }^{18}$

15. See Robert E. Sullivan, All About Royalties, 16 RocKY MTN. MiN. L. InST. 7 (1971), ("The concepts that minerals are capable of private ownership and that royalty is a payment for extraction of minerals may be viewed as incorporated into the laws of the United States as a part of the common law.").

16. Dante L. Zarlengo, Royalty Concepts and Present Applications to Federal Oil and Gas and Coal Leases, 19 ROCKY MTN. MiN. L. INST. 1 (1986).

17. Id.; John S. Lowe, Defining the Royalty Obligation, 49 SMU L. REV. 223, 258 (1996).

18. Zarlengo, supra note 16. 
While today a royalty is akin to a type of rent, at common law it was viewed as the actual portion of minerals due to the crown in return for the privilege of extraction. ${ }^{19}$ This concept of a royalty "in kind" derived from Roman law and Emperor Gratian's decree establishing the Empire's right to all mined gold and silver and one-tenth part of all other mined minerals. ${ }^{20}$ Under Roman law, the Roman government and landowner each received one-tenth of the mined minerals, which resulted in a total royalty of twenty percent. ${ }^{21}$ The British Crown adopted this Roman concept of the right to mined minerals. In addition to asserting its royal right derived from Roman law, the British Crown also supported its right to a portion of mined minerals with pragmatic concerns such as its need for minerals to use in coinage. ${ }^{22}$

In England, the type of mine defined the recipient of the royalty: for "royal mines" the royalty was paid to the sovereign, whereas for other mines it was paid to the landowner for "the privilege of working the property." ${ }^{23}$ As the common law developed, the English monarch maintained exclusive ownership over all silver and gold discovered, called the "regalian right." In contrast, royalties taken on other minerals functioned as a "rent or tax" or were sold fee simple, depending on local customs. ${ }^{24}$ For example, in the tin mines of Cornwall, the right to work was given to all "free tinners" so long as a portion of all minerals extracted were transferred back to the owner, usually about one-fifteenth of the product. ${ }^{25}$ Mining lead in the mines of Derbyshire was made contingent on returning one-thirteenth of the minerals extracted to the crown or the land's lessee. ${ }^{26}$

Outside of England, the early concept of a "royal fifth" (quinto real or quinto del rey in Spanish and Portuguese, respectively) reserved to the monarch twenty percent of all precious metals and other commodities extracted by mining, acquired by the monarch's subjects as war loot, or found as treasure. The "royal fifth" was instituted in

19. $I d$.

20. See Katharine K. DuVivier, Sharing the Wealth: Mineral Royalties in Kind, 17A ROCKY MTN. Min. L. INST. 11 (1985) (citing W. BAINBRIDGE, A TREATISE ON THE LAW OF MiNES AND MineRALS 106-08 (5th ed. 1900)) (discussing royalties in kind).

21. See Owen L. Anderson, Royalty Valuation: Should Royalty Obligations Be Determined Intrinsically, Theoretically, or Realistically? Part 1, 37 NAT. RESOURCES J. 547 (1997) (discussing royalties on marble) (citing CLYDE PHARR, THE THEODOSIAN CODE AND NOVELS AND THE SIRMONDIAN CONSTITUTIONS, Book X, Title 19, 284 (1952)).

22. See DuVivier, supra note 20.

23. Sullivan, supra note 15 (citing 1 LINDLEY, MINES $\S 8$ (3d ed. 1914)).

24. Id. (citing 1 LINDLEY, MINES $§ \S 2,3$ (3d ed. 1914); 2 SNYDER ON MiNES $§ 1276$ (1902)).

25. LINDLEY, MINE $\S \S 2,5$ (3d ed. 1914).

26. Id. at $\S 8$. 
Medieval Muslim states, Christian Iberian kingdoms (including Spain and Portugal), and their overseas colonial empires during the age of exploration..$^{27}$ In 1783, King Charles III of Spain dictated the Mining Ordinances for New Spain whereby a "fifth part" of the value of all minerals produced from mines located in New Spain (much of presentday Central and South America) was reserved to the crown. ${ }^{28}$

A similar story unfolded in American colonies. In all land grants, the British Crown reserved for itself a certain fixed proportion of minerals discovered in the colonies. ${ }^{29}$ For example, the Charters of Massachusetts, Rhode Island, Connecticut, Pennsylvania, Maryland, and Virginia reserved one-fifth part of all the gold and silver ore as rent to the British Crown. ${ }^{30}$ After the American Revolution, the new United States government sought royalties, too: in 1785, the Continental Congress reserved one-third part of all gold, silver, lead, and copper mines. ${ }^{31}$ According to one historical account, "[i]t was the force of precedent rather than considerations of public and economic policy that suggested those provisions of the ordinance reserving a part of the mineral lands for the use of the government." ${ }^{32}$ The U.S. government later changed course, declaring all mineral lands "free and open to exploration and occupation, subject to such regulations as may be prescribed by law." ${ }^{33}$

The "regalian" doctrine of ownership of royal metals based on the crown's entitlement to these metals, a theory that prevailed in countries such as England and Spain, was not formally recognized in the United States. ${ }^{34}$ Although U.S. mining law has been influenced by mining law

27. The specification of the twenty percent royalty rate on war loot was institutionalized from the start of the Islamic conquest, with the rate set down in the Quran, in Sura VIII (AlAnfal), verse 41: "And know that out of all the booty that ye may acquire (in war), a fifth share is assigned to Allah ...." (Quran 8:41).

28. Charles Thomson, The Ordinances of the Mines of New Spain: Translated FROM THE ORIGINAL SPANISH, WITH OBSERVATIONS UPON THE MINES AND MINING AsSOCIATIONS 142, 147 (1825).

29. See LINDLEY, supra note $25, \S 31$, at $62-63$ (describing the crown's practice of inserting clauses into land grants that reserve fixed portions of the royal metals that were discovered).

30. $I d$.

31. Id. $\S 30$, at 61 .

32. Id. $\S 31$, at 54 .

33. DuVivier, supra note 20; see also LINDLEY, supra note $25, \S 55$, at 91.

34. See LindLEY, supra note $25, \S 80$, at 123 ("A grant or conveyance by the United States carries all minerals, unless reserved expressly or by implication in the law or instrument purporting to pass the title."). 
from other countries, it largely derives from express congressional legislation, state law, and local rules and customs established in different regions. ${ }^{35}$

The rest of this article explores the theoretical and historical development of natural resource royalties in the United States. In the next Part, the article describes the economic justifications for natural resource royalties. These justifications, while often not the explicit drivers of royalty rates, were influential in defining how stakeholders contemplated and explained royalty rates.

\section{THEORETICAL JUSTIFICATIONS FOR ROYALTIES}

Economists have justified mineral royalty payments as the owner's share of differential returns on certain mines given their higher productivity (economic rent) ${ }^{36}$ or as payments to the owner for minerals removed (user cost). ${ }^{37}$ Increasingly, economists have considered the relevance of negative externalities from the extraction or use of minerals in the calculation of socially optimal royalty rates. ${ }^{38}$ This Part describes this economic literature.

\section{A. Royalty as Economic Rent}

The concept of economic rent has been used as a justification for royalty payments. ${ }^{39}$ Economic rent (also referred to as the Ricardian rent) is a payment to the owner of a factor of production that exceeds the amount necessary to keep the factor in its current employment. ${ }^{40}$ David Ricardo first explored the idea of an agricultural land rent equal to the advantage of using a tract of land in its most productive use

35. Id. $\S 81$, at 124 .

36. See, e.g., Larry L. Dale, The Pace of Mineral Depletion in the United States, 60(3) LAND ECON. 255, 263 (1984) (explaining how the market usually reflects the fair price of these resources); John H. Mutti \& William E. Morgan, Changing Energy Prices and Economic Rents. The Case of Western Coal, 59 LAND ECON. 163, 164-65 (1983) (explaining that royalty payments can represents the "diminution in the value of the mine"); John E. Orchard, The Rent of Mineral Lands, 36(2) Q.J. ECON. 290, 290 -91 (1922) (describing the disagreement among academics over how to explain royalty payments); ROSS GARNAUT \& ANTHONY CLUNIES ROSS, TAXATION OF MineRAL RENTS 1, 17-36 (Clarendon Press Oxford 1983) (providing an overview of taxation and policy issues related to mineral rent).

37. See, e.g., Mutti \& Morgan, supra note 36; Orchard, supra note 36; GARNAUT \& CLUNIES Ross, supra note 36.

38. See, e.g., Dale, supra note 36; Mutti \& Morgan, supra note 36; Orchard, supra note 36; GARNAUT \& CLUNIES ROSS, supra note 36.

39. See, e.g., Dale, supra note 36; Mutti \& Morgan, supra note 36; Orchard, supra note 36; GARNAUT \& CLUNIES ROSS, supra note 36.

40. DAVID RicARdo, ON THE PRINCIPLES OF POLITICAL ECONOMY AND TAXATION (London 1817), http://www.econlib.org/library/Ricardo/ricP1a.html (Chapter 2). 
relative to the advantage of using the marginal tract (or the best rentfree tract) for the same purpose. ${ }^{41}$ In other words, land rent is the payment to the owners of especially fertile land in return for the production advantage (or cost savings) associated with using that land.

Just as agricultural land varies in its fertility, mineral mines vary in their production costs due to deposit quality and proximity to markets. For this reason, some mines may earn economic rent. For example, a coal mine on land with superior coal deposits (say, thicker deposit seams located closer to the surface) will be able to produce coal at lower cost than will a mine on land with inferior coal deposits (such as narrow deposit seams located at great depth). ${ }^{42}$ Similarly, a mine located near an industrial or shipping center will have lower production costs than a mine located farther away and subject to higher transportation charges. ${ }^{43}$ The owners of superior mines earning economic rent will be able to charge higher royalties. These royalties tend to be seen as fair, enabling the mineral owner to share in the economic rent arising from the mineral's superior quality. ${ }^{44}$ Moreover, unlike other forms of taxation, royalties imposed on economic rent would not, in principle, distort behavior. ${ }^{45}$ Of course, if the private costs of production do not fully account for the social costs of production and no corrective policy measures are taken, then the resulting level of production would not be socially optimal. In such a case, even if royalties capture more than the economic rent and thereby reduce production, the "distortion" in behavior would actually result in a production level closer to the socially optimal level. ${ }^{46}$

There is evidence that U.S. royalties have historically been directed, at least in part, at capturing economic rents. ${ }^{47}$ John Orchard,

41. Id.

42. See Orchard, supra note 36, at 298. ("The extrinsic powers include transportation and market; the intrinsic, thickness of seam, depth, angle of seam, faulting, nature of roof, and the like.").

43. Id., at 298-99.

44. See GARnAUt \& CluniEs Ross, supra note 36, at 21-22.

45. Even assuming that there are no externalities and that the royalty perfectly captures economic rent, it is possible that, in the long run, the royalty will distort behavior because by cutting into the economic rent, it will reduce incentives for discovering high-quality mineral deposits.

46. CEA COAL REPORT, supra note 5, at 11-12.

47. Whether a royalty actually captures economic rent is a separate matter. Such a royalty would be specific to each site, based on ex ante predictions of economic rent given the site's attributes and associated production costs, which may itself diverge from ex post realized costs. See Radford Schantz, Jr., Purpose and Effects of a Royalty on Public Land Minerals, 20(1) RESOURCES POLICY 35, 37 (1994) (analyzes the royalties for minerals on public land). Generally speaking, a federal royalty could not perfectly capture such rent. See, e.g., P.S. DASGUPTA \& G.M 
in his analysis of the history of mineral rents, argued that in the United States, royalties were "partly compensation for the mineral removed and partly surplus or economic rent arising through superiority of some mines over others." $48 \mathrm{He}$ quoted the secretary of the American Institute of Mining Engineers explaining U.S. royalty rates in 1889 as follows: "With us the royalty always settles itself according to special advantages. The lowest royalty is the royalty that must be paid, or else the landowner would not care to let the mine be worked. On top of that, you have all those higher royalties coming in to represent special natural advantages." ${ }^{\circ 9} \mathrm{He}$ also quoted a Birmingham mining engineer as stating in 1919 that "strictly speaking, royalties are partly rent or income, and partly capitalization of assets."

Orchard also examined early royalty rates and found that they tended to be higher when economic rents were likely to be higherthat is, when the costs of extraction were low due to the coal's "accessibility, quantity, thickness, depth, value, and other conditions that affect the cost of its extraction." ${ }^{51}$ For example, Kentucky in 1910 had a royalty of 8 cents per ton on coal from 3- to 4-feet-thick seams, 10 cents on coal from 4- to 5-feet-thick seams, and 12 cents on coal from 5- to 6-feet-thick seams. ${ }^{52}$ Orchard also noted that the U.S. Geological Survey, in its 1910 classification and valuation of government coal lands, placed a significantly higher value on lands less than 15 miles from a completed railroad. ${ }^{53}$ According to Orchard, these U.S. practices were consistent with practices in European countries at the time..$^{54}$

HeAl, ECONOMIC THEORY AND EXHAUSTIBLE RESOURCES 362 (1980) ("The subject is particularly murky, since the structure of optimum taxes often depends sensitively on the constraints the government faces in wielding the various controls available to it."); JAMES OTTO et Al., Mining Royalties: A Global Study of Their ImPACT ON InVestors, GOVERNMENT, AND CIVIL SOCIETY 30, 94 (World Bank 2006).

48. Orchard, supra note 36, at 307-08. Notably, Orchard and the American mining operators that he quotes also refer to user costs, a concept discussed infra in the next Section, as partly justifying the royalty rate.

49. Id. at 296 (quoting Rossiter W. Raymond, an American mining engineer, then secretary of the American Institute of Mining Engineers, in his testimony before the British Royal Commission on Mining Royalties appointed in 1889).

50. Id. (quoting T. H. Bailey, a Birmingham mining engineer, testifying before a 1919 British coal commission).

51. Id. at 298

52. Id. at $299-300$.

53. Id. at 299 .

54. Id. at 302-03. Most illustrative is the French practice in 1890 of setting variable royalty rates that ranged from $1 / 6$ th of yield for coal mined from the shallowest and thickest seams to $1 / 80$ th of the yield for coal mined from the deepest and thinnest seams. See id. 
The concern about the "special advantages" of certain mines was also evident in the testimony before Congress prior to the adoption of the Federal Coal Leasing Amendments Act of 1976. The concern apparently motivated the lower royalty rate on coal produced from underground mines, which were thought to be more costly to operate. Legislative history is discussed more thoroughly in the next Part.

The discussion of economic rent typically does not involve discussion of externalities. But, if environmental regulation is otherwise adopted, a "special advantage" of a mine might include its low environmental externalities. Such a mine would earn economic rent that the public, in turn, could capture through the royalty rate. Mines that generate high environmental externalities might earn no economic rent or become unprofitable to operate at all. In such a case, the mineral owner may prefer for the mineral to stay undeveloped, a concept discussed in the next Section.

\section{B. Royalty as User Cost (or Compensation for Liquidated Wealth)}

Unlike the agricultural land on which Ricardo based his theory of economic rent, coal is a nonrenewable resource. Its supply is exhausted in the long run, at which point economic rent becomes zero. Because of the unique characteristics of nonrenewable resources, some economists have distinguished between royalties on nonrenewable resources and rents, influenced by the work of Harold Hotelling..$^{55}$ In 1931, partly in response to the conservation movement, Hotelling developed a model of the optimal rate of extraction of a nonrenewable resource over time. ${ }^{56}$ According to Hotelling, profit-maximizing competitive firms will extract a mineral resource until the market price of the resource equals the production costs of the last unit plus a cost equal to the net present value of the forgone future profits had the resource remained in the ground (in other words, the cost of not being

55. This issue has attracted significant debate in economics. Some economists argue that royalties for nonrenewable resources are not rents, see, e.g., ALFRED MARSHALL, PRINCIPLES OF ECONOMICS Book V, Chapter X, 254, (Macmillan \& Co., 8th ed. 1920) (stating that "[a]

royalty is not a rent, though often so called."), while others argue that the concept of rent is relevant, see e.g., Lewis Cecil Gray, Rent Under the Assumption of Exhaustibility, 28(3) Q.J. ECON. 466, 467-70 (1914) (arguing that "the present value of the surplus income from the mine ... is the present value of the total rent in which it will yield"). Still others conclude that royalties include both economic rent and user cost. See Orchard, supra note 36, at 290-97; see also Ben Fine, Landed Property and the Distinction between Royalty and Rent, 58(3) LAND ECON. 338, 343-45 (1982) (arguing that the question itself is irrelevant from a general equilibrium context).

56. Harold Hotelling, The Economics of Exhaustible Resources, 39(2) J. POLITICAL ECONOMY 137-75 (1931). 
able to use the resource in the future). This latter cost is now referred to as the Hotelling rent or user cost.

Economist Alfred Marshall explained that, conceptually, a royalty is akin to the user cost because it compensates the owner of the mineral for the reduced opportunity to produce the mineral in the future. ${ }^{57} \mathrm{~A}$ tax on the user cost, unlike a tax on economic rent, would distort firm behavior because it would incentivize a firm to leave mineral resources in the ground for the future. ${ }^{58}$ Hotelling's model implies that the optimal royalty schedule must induce the mining firm to exhaust the mine in such a way that marginal net benefits grow over time at the rate of discount..$^{59}$

Under this framework, the government would be justified in collecting a high royalty if the stock of the mineral were limited even if there were no economic rents. ${ }^{60}$ On the flip side, if the stock of the mineral were large relative to anticipated demand, the royalty would be lower. ${ }^{61}$ Arguing in favor of this aspect of a royalty, Orchard explains that the owner of a currently unprofitable coal deposit, one that does not earn economic rent, would not allow any mining without compensation, as he would "gain[ ] nothing" and "lose[ ] an asset that may bring in an income for himself or his heirs with a change in market conditions." ${ }^{2}$ The owner would demand payment equal to the marginal or minimum royalty necessary to compensate the owner for his loss even in the absence of economic rent. ${ }^{63}$

Despite its intuitive appeal, however, there is little evidence that user costs were a significant component of historical royalty rates for coal in the United States. This is largely because the supply of coal has not been perceived to be scarce, implying user costs close to zero, ${ }^{64}$

57. MARSHALL, supra note 55 .

58. See, e.g., Dale, supra note 36.

59. See Hotelling, supra note 56, at 165-69; Gerard Gaudet et al., Optimal Resource Royalties with Unknown and Temporally Independent Extraction Cost Structures, 36(3) INT'L ECON. REV. 715, 715 (1995) ("The well known Hotelling rule of natural resource extraction (Hotelling 1931) implies that if the mine owner wishes to maximize the present value of net benefits over the life of the mine, the royalty schedule must induce the mining firm to exhaust the mine in such a way that marginal net benefits grow over time at the rate of discount.").

60. See Mutti \& Morgan, supra note 36.

61. Id.

62. Orchard, supra note 36 , at 295.

63. Id. at 296 .

64. See OTtO ET AL., supra note 47, at 29; Mutti \& Morgan, supra note 36 ("The federal government is receiving substantially higher royalty rates on new leases, but the higher current rates do not reflect a Marshallian royalty because the stock of western coal is virtually unlimited."). 
though economic theory would predict an increasing royalty rate over time as the resource becomes scarcer.

Nonetheless, the concept of user costs has historically been relevant as a justification for royalty rates in the United States. U.S. mining operators and policymakers were aware of the user cost when determining and evaluating possible royalty rates. Both American mining operators quoted by Orchard referred to user costs in addition to economic rents - or, in their words, the part of the royalty "that must be paid, or else the landowner would not care to let the mine be worked," or the part that essentially represented the "capitalization of assets." ${ }^{65}$ And, in congressional hearings on the Federal Coal Leasing Amendments Act of 1976, there was concern that "it may not be desirable to encourage underground mining [via a lower royalty rate] until technology has evolved which will allow a higher percentage of recovery." ${ }^{66}$ That concern is fundamentally about forgoing future less costly mine productivity as a result of present mining.

Such a concern, in turn, can be analogized to concern about costly externalities caused by coal production. The landowner receives a royalty payment from coal production, but the landowner's total benefit is reduced by the environmental damage to his land from the production. Such a landowner may prefer to wait to extract the coal until technology evolves that makes coal production less environmentally costly. When the government owns the land and minerals, concerns about the net social costs of production become even more relevant, as discussed in the next Section.

\section{Royalties and Externalities}

The concepts of economic rent and user cost roughly suggest that maximum net benefits would accrue to the public when the government directs royalties at capturing all economic rent and compensating the public for the user cost. But when resource extraction produces environmental and other costs to social welfare, unless corrective measures are taken, the level and rate of exploitation of the resources will be higher than is socially optimal. ${ }^{67}$ The concepts

65. Orchard, supra note 36, at 296.

66. Federal Coal Leasing Amendments Act of 1975: Hearing on S. 391 Before the Subcomm. On Minerals, Materials and Fuels of the S. Comm. On Interior and Insular Affairs, 94 Cong. 504 app. (1975) [hereinafter Hearing on S. 391]; see also Orchard, supra note 36, at 295-96.

67. See William D. Schulze, Optimal Use of Non-Renewable Resources: The Theory of Extraction, 1 J. ENVTL. ECON. \& MGMT. 53, 54 (1974) (arguing that considering cumulative environmental damages, Hotelling's competitive extraction cannot yield Pareto optimal results); Timothy R. Muzondo, Mineral Taxation, Market Failure, and the Environment, 40(1) IMF STAFF 
of economic rent and user cost do not directly address what the government should do in the face of such externalities. Nonetheless, economics provide a framework for thinking through this complex issue.

As the White House Council for Economic Advisors recently explained, ensuring the optimal extraction of mineral resources on public land is akin to solving a principal-agent problem: the government (the principal) directs a coal firm (the agent) to efficiently extract the coal and return economic profits to the government. ${ }^{6}$ When the government is the mineral owner, its objective should be to develop the resource in such a way as to generate maximum net benefits for the public. ${ }^{69}$ In the best-case scenario, the government would itself efficiently extract the coal using the lowest-cost approaches at the optimal rate, taking into account both direct and external costs of production, and would keep economic rents and user costs for taxpayers' benefit.

In reality, the U.S. government does not extract the resources for itself and instead relies on coal firms to do so. ${ }^{70}$ Thus, a royalty payment would in theory allow the public to enjoy maximum net benefits from extraction by forcing the coal firms to internalize negative externalities and align their incentives with those of the government. ${ }^{71}$ This justification for a royalty is implicit in Orchard's characterization of the minimum royalty as the landowner's compensation for otherwise uncompensated environmental externalities of mining such as "the marring of the beauty of the locality with an ugly mine mouth, a black

PAPERS 152, 160-62 (1993) (arguing that "cumulative environmental externalities will reduce the rate of growth of marginal profits over time").

68. CEA COAL REPORT, supra note 5, at 2, 10; see also Gaudet et al., supra note 59, at 716 (characterizing the situation as a principal-agent problem in which the government seeks to capture all economic rents).

69. See CEA COAL REPORT, supra note 5, at 10 ("A common theme among all of these examples is the goal of maximizing return to the taxpayer from the use of the public resource to the extent feasible."); see also GARNAUT \& CLUNIES Ross, supra note 36, at 3-4 (noting that maximizing government revenue can coincide with maximizing social welfare when, among other things, "externalities are compensated"); Schantz, supra note 47, at 36 ("When the government/landowner sells mineral rights, the rent ought to cover expected opportunity and environmental costs arising from anticipated mining activities."); Orchard, supra note 36, at 313; OTTO ET AL., supra note 47, at 29-30.

70. See CEA COAL REPORT, supra note 5, at 10 (arguing that the government should align its incentive with the coal companies to maximize public benefit).

71. See Muzondo, supra note 67, at 162 ("These results [after accounting for negative externalities in Hotelling's model] suggest that in mining, where environmental taxes are rarely imposed, but specific taxes are popular with governments, such taxes can be considered proxies for current environmental externalities.”); Schantz, supra note 47, at 36. 
coal tipple, or a dump heap." 72 The association of royalty payments with payments for residual environmental costs is also implicit in the fact that about half of the federal government's revenues from royalty payments are returned to the states where mining occurs. ${ }^{73}$ The implications of this revenue-sharing policy are discussed in more detail in the next Part.

The idea that the royalty can help align producer incentives with those of the government by addressing externalities is not new. For example, the existence of positive externalities such as "the stimulation of an infant industry and the development of mineral resources" was used as a "principal rationale" for imposing no royalties on the discovery and extraction of certain minerals in $1872 .{ }^{74}$ Historically, the fact that "[o]il and gas operations have minimal effect on surface use compared to coal operations which are usually highly disruptive to the surface" has been offered as a justification for different royalty rates between oil-and-gas extraction and coal production. ${ }^{75}$ The legislative history for the Federal Coal Leasing Amendments Act of 1976 also indicates that U.S. policymakers were aware that "[o]ne manner by which [more costly] underground mining can be encouraged is by the use of a lower royalty rate on coal mined by underground methods." ${ }^{, 76}$ More recently, Radford Schantz, Jr., a member of a 1993 task force assembled by Interior for the economic analysis of royalty proposals, recalled that compensation for environmental impacts was a justification offered for a royalty at the time. ${ }^{77}$ In fact, according to him,

72. Orchard, supra note 36, at 295-96. In addition, this justification is implicit in the concern that "it may not be desirable to encourage underground mining [via a lower royalty rate] until technology has evolved which will allow a higher percentage of recovery be underground mining" - that is, a concern that society may benefit more if the resource is left in the ground and potentially mined at lower social cost in the future. Hearing on S. 391, supra note 66.

73. See, e.g., Robert H. Nelson, The Making of Federal CoAl Policy 1, 225 (Duke Univ. Press) (1983) (arguing, in 1981, that the royalty rate is excessive partly because states can, and do, get compensated for the "public costs of coal mining" through direct taxes).

74. Salvatore LazZari, Cong. Research Serv., RL34268, The Federal Royalty and TAX TREATMENT OF THE HARDROCK Mineral INDUSTRY: AN ECONOMIC ANALYSIS, CONGRESSIONAL RESEARCH SERVICE REPORTS - TAXATION 20 (2008). Other commentators have noted that, practically speaking, the government would have been unable to enforce and collect a royalty in some regions, even if it did set one at that time.

75. Royalty Concepts and Present Applications to Federal Oil and Gas and Coal Leases, 19D ROCKY MTN. MIN. L. INST. 1 (1986). The fact that offshore oil-and-gas royalty rates are now significantly higher than minimum onshore coal royalty rates $(18.75$ percent for offshore drilling in the Gulf of Mexico versus 12.5 percent for surface-mined coal and 8 percent for underground coal) further underscores the need to reevaluate coal royalty rates.

76. See Hearing on S. 391, supra note 66.

77. See Schantz, supra note 47 , at 36. 
an initial proposal for dealing with pollution from abandoned mines involved using revenue from royalty payments, "underscoring the environmental aspect of the royalty." "T8 There is also evidence outside the United States of governments using royalties to motivate changes in firm behavior. For example, in 1987, New Zealand introduced royalty payments to help reduce geothermal extraction from the Rotorua geothermal field. ${ }^{79}$

Rather than favoring the use of royalties to achieve environmental goals, however, economists often emphasize that, from the standpoint of economic efficiency, direct economic instruments (such as a specific price or quantity condition on pollutants from mining activities) may be better suited to control environmental externalities. ${ }^{80}$ This is because these instruments could be directed at specific environmental problems and pollutants. Much of this concern is motivated by the idea that many environmental externalities produce site-specific damages, ${ }^{81}$ though this concern is notably absent in the context of externalities from global pollutants like carbon dioxide and methane. Notwithstanding efficiency concerns, it is undeniable that the financial and environmental motivations underlying royalty payments "are not really separate" because, as Schantz explains, "[w]hen correctly measured, the wealth embodied in in-ground minerals is an indicator of their social utility value" and "[a]s such, it ought to be net of the social costs of mining, including the value of environmental impacts." 82 In particular, when there are no direct instruments in use that require producers to internalize environmental externalities, royalty rates that account for these externalities can help to avoid undesirably high levels of production.

In light of these considerations, Schantz models the government's supply of a royalty as follows. ${ }^{83}$ The government landowner weighs the

78. Id.

79. See Bradley J. Scott \& Ashley D. Cody, Response of the Rotorua Geothermal System to Exploitation and Varying Management Regimes, 29 GEOTHERMICS 543, 579 (2000). The royalty was effective, eventually resulting in signs of recovery for the reservoir. See id.; Brett W. O'Shaughnessy, Use of Economic Instruments in Management of Rotorua Geothermal Field, New Zealand, 29 GEOTHERMICS 539, 542 (2000).

80. See, e.g., Mutti \& Morgan, supra note 36, at 167 ("Stated differently, assuming impact costs vary among locations, it is desirable from an efficiency perspective to adopt policies that discriminate according to site-specific impact costs rather than financing impact through severance taxes that are imposed at a uniform rate."); Schantz, supra note 47, at 36.

81. Mutti \& Morgan, supra note 36; Schantz, supra note 47, at 36.

82. Schantz, supra note 47 , at 36 .

83. Id. at 39; see also Orchard, supra note 36, at $295-96$ (suggesting the minimal royalty compensates the landowner in part for otherwise uncompensated externalities of mining such as 
value of income from the sale against the value of what it gives away. ${ }^{84}$ The government determines this latter value by evaluating: (1) opportunity cost, defined as the value of alternative uses of the land; (2) user cost; and (3) residual environmental impacts not mitigated by other laws or regulations. ${ }^{85}$ These considerations form the minimum royalty that the government would accept at each site (comparable to Orchard's statement of the minimum royalty). The demand for leasing land for exploration and eventual mining, in turn, is determined by the prospector's assessment of the expected value of exploration at the site. Assuming competitive bidding for each site, the optimal royalty that emerges is equal to the supply price for the site (the opportunity cost, user cost, and environmental cost) plus, if applicable, a premium for economic rents at certain sites generated by competition among prospectors. ${ }^{86}$ At the marginal site, this premium would be zero, and the royalty would equal the supply price. ${ }^{87}$

Economists have modeled the effect of various forms of royalty and taxes in bringing production closer to the socially optimal level and rate, but many of the effects are ultimately dependent on the type of assessment scheme chosen for the royalty. ${ }^{88}$ In general, however, royalties take the form of ad valorem taxes, that is, taxes on the amount or value of the resource. ${ }^{89}$ Although an analysis of the optimal form of a royalty is beyond the scope of this article, there is a robust literature in economics about setting an optimal ad valorem tax in the context of externalities. ${ }^{90}$ For example, economist Evan F. Koenig has argued that ad valorem taxes combined with specific taxes are a viable policy

\footnotetext{
"the marring of the beauty of the locality with an ugly mine mouth, a black coal tipple, or a dump heap").

84. Schantz, supra note 47 , at 39 .

85. Id.

86. Id. at 40 .

87. Id.

88. See, e.g., Muzondo, supra note 67, at 164-65 (summary table); Ita Falk, Dynamical Ecologic Taxes: Public Control for Interrelated Renewable Resources, 13 RESOURCE \& ENERGY 381 (1991) (evaluating various policies to deal with pollution in the context of Interrelated renewable resources).

89. See GARNAUT \& ClUNIES Ross, supra note 36, at 92-94.

90. See, e.g., Evan F. Koenig, Indirect Methods for Regulating Externalities under Uncertainty, 100(2) Q.J. ECON. 479 (1985) (calculating how the ad valorem tax rate can influence externalities); Jukka Pirttila, Specific Versus Ad Valorem Taxation and Externalities, 76(2) J. ECON. 177 (2002) (examining "the choice between specific and ad valorem taxes when the production of a good, produced under imperfect competition, creates harmful externalities").
} 
option that may outperform other regulation in appropriately accounting for externalities given uncertainty under certain conditions. $^{91}$

\section{Mineral Royalties IN THE United StATES}

Legislative history concerning coal and other mineral resource extraction in the United States demonstrates that leasing policies and royalty rates have consistently been used as policy levers to advance such goals as encouraging development and compensating the public for the removal and value of mineral resources. Congress has repeatedly made policy judgments with respect to the value of mineral resources; the desirability of promoting the development of particular types of resources; and, beginning in the 20th century, the best way to allocate revenue from resource extraction to the public and to communities affected by resource development. In addition, Congress has vested the Secretary of the Interior with broad authority to set royalty rates and manage federal fossil fuel leasing programs in order to best serve the national interest.

\section{A. Early U.S. Mineral Development and the Mineral Leasing Act}

One of the earliest records of the United States' contemplation of mineral rights appears in the Northwest Territory in the Land Ordinance of May 20, 1787, which provided that "there shall be reserved ... one-third part of all gold, silver, lead, and copper mines, to be sold, or otherwise disposed of as Congress shall hereafter direct." ${ }^{2}$ But as the settlement of the United States expanded westward in the 19th century, the general policy of public land management was to convey land to private ownership in order to encourage settlement, farming, and mining. ${ }^{93}$ The gold rush of 1848 led Congress to consider mineral resource legislation, but it failed to take meaningful action to control western mineral resources, relying instead on local laws and customs already in place to manage mining. ${ }^{94}$

91. Koenig, supra note 90, at 491-92.

92. John C. LACY, Historical Overview of the Mining Law: THE Miner's Law Becomes LaW, IN THE Mining LAW of 1872: A LEgAl AND Historical ANALysis 13, 16 (1989).

93. Shelby D. Green, Reclaiming the Public Domain by Repeal of the Mining Law of 1872, 6 HofSTRA PROP. L. J. 85, 152 (1993) (citing LACY, supra note 92, at 16-17); LINDLEY, supra note $25, \S \S 54-57$, at $81-85$ (declaring the policy of the United States to promote westward expansion).

94. Green, supra note 95, at n.21; see also LINDLEY, supra note 25 , § 48, at 76-78 (describing competing concerns in Congress); LINDLEY, supra note $25, \S 41$, at $63-64$ (describing the rise of gap-filling local customs). 
Starting in the second half of the 19th century, Congress began to treat coal differently from other minerals, as its value as an energy source became clear. In 1864 and again in 1873, Congress enacted the Coal Lands Acts authorizing private purchase in fee simple ${ }^{95}$ of lands classified by the Department of the Interior as valuable for coal; those statutes set a maximum limit of 160 acres on individual entry and minimum prices of $\$ 10$ to $\$ 20$ per acre.${ }^{96}$ Congress enacted the General Mining Law of 1872 to regulate other minerals; that statute authorized the sale of public lands in fee simple to mining claimants at rates of $\$ 2.50$ to $\$ 5.00$ per acre..$^{97}$ The Coal Lands Acts and General Mining Act of 1872 helped develop the West by allowing individuals to obtain exclusive rights to mine billions of dollars' worth of gold, silver, coal, and other hardrock minerals from federal lands without having to pay a federal royalty. ${ }^{98}$

At the turn of the 20th century, Congress began to discuss ways to retain federal control of its mineral resources out of concern for the price and supply of coal. ${ }^{99}$ Congress passed the Coal Lands Act of $1909{ }^{100}$ which authorized the issuance of patents to "[a]ny person who has in good faith located, selected, or entered under the nonmineral land laws of the United States any lands which subsequently are classified, claimed, or reported as being valuable for coal," upon proof of compliance with land laws. ${ }^{101}$ The Act, however, mandated that the patent "shall contain a reservation to the United States of all coal in said lands, and the right to prospect for, mine, and remove the same." 102 Thus, the statute aimed to reconcile the twin goals of the federal government at that time: to settle the West and to retain federal ownership of valuable mineral resources.

Legislative history leading up to the passage of the Mineral Leasing Act of 1920 reveals a desire among members of Congress to

95. Fee simple refers to permanent and absolute ownership of property, with freedom to dispose of it at will.

96. See Act of July 1, 1864, ch. 205, § 1, 13 Stat. 343 (allowing private individuals to bid on "mines"); Act of Mar. 3, 1873, ch. 279, § 1, 17 Stat. 607.

97. See 30 U.S.C. $\$ \S 26,29,30,37$ (2012).

98. U.S. GOV'T ACCOUNTABILITy OFFICE, HARDrock Mining: INFORMATION ON STATE Royalties And the Number of Abandoned Mine Sites And HaZARds (July 14, 2009), http://www.gao.gov/assets/130/123013.pdf.

99. See Hearings on Coal Lands and Coal-Land Laws of the United States Before the House Comm. on Pub. Lands, *4 59th Cong. 11 -13 (1907) (testimony of Edgar E. Clark, Interstate Commerce Commissioner).

100. Act of Mar. 3, 1909, ch. 270, 35 Stat. 844 (codified at 30 U.S.C. $§ 81$ ).

101. 30 U.S.C. $\$ 81$ (2012).

102. Id. 
retain public ownership of mineral resources. ${ }^{103}$ Royalty rates were described as a way to "assure the Government an adequate return from lessees," 104 and represented the way in which "the community shares in the element of value." ${ }^{105}$ Some representatives from states with federal land within their borders expressed concern that "the communities in which these great resources lie would not obtain any considerable part of the cream of the values taken from them in the way of royalty." 106 This concern has persisted today, in calls for a greater portion of royalties to be returned to states in which minerals lie and to coastal states closest to federal offshore mineral tracts. (See discussion later in this Section.) Other members of Congress were apprehensive about the broad grant of authority to Interior in the draft bill that would become the Mineral Leasing Act, stating that "the Secretary of the Interior is given practically unlimited authority as to the granting and the terms and conditions of leases." 107

The Mineral Leasing Act of 1920 provides for the disposition of reserved minerals, including coal, oil, and natural gas, on federal lands subject to enumerated lease terms and payments. The Act sets a minimum royalty rate for "the privileges of mining or extracting the coal in the lands covered by the lease" payable to the United States of "not ... less than 5 cents per ton of two thousand pounds." 108 The Mineral Leasing Act also states that the Secretary of the Interior can include coal, oil, or natural gas lease terms that she or he deems necessary "to insure the sale of the production of such leased lands to the United States and to the public at reasonable prices, for the protection of the interests of the United States, for the prevention of monopoly, and for the safeguarding of the public welfare." 109 Thus, lease terms were to be adjusted by the Secretary in order to advance national interests. Royalties during this period were based on cents per

103. Senator Walsh highlighted issues with the prior fee simple system and the goal of retaining federal control over federal lands, stating, "Some possible criticism might be made, as it seems to me, of an act which would contemplate the complete alienation of the land, by which they were to pass entirely out of the ownership and control of the Government of the United States, that by reason of legislation of that character they might possibly get into the hands of some great interest - the oil lands, for instance, getting into the hands of Standard Oil Co." James D. Harris, The Linowes Commission - Where Are We 25 Years Later?, 1 ROCKY MTN. MIN. L. INST. 3, 3-7 (2007) (quoting 43 Cong. Rec. 4251 (1919)).

104. 51 Cong. Rec. 14,945 (Sept. 10, 1914) (statement by Mr. Thomson of Illinois).

105. Id. at 14,955 .

106. Id. at 14,951 .

107. Id. at 14,954 .

108. Mineral Lands Leasing Act of February 25, 1920, Sec. 7.

111. 30 U.S.C. $\$ 187$ (2012). 
ton and varied with the quality of coal and associated difficulties of mining it; this method changed to "a percentage of value royalty" tailored to mining conditions and coal quality in the late 1960s. ${ }^{110}$

\section{B. "Fair Market Value" and Royalties as Compensation for Externalities}

By the early 1970s, the environmental movement was gaining momentum in the United States. ${ }^{111}$ Policymakers sought to reconcile competing federal policy aims, such as producing domestic energy resources and ensuring environmental protection. Legislative history leading up to the passage of the Federal Land Policy and Management Act in 1976 shows that Congress sought to use federal royalties as a policy lever to help effectuate multiple goals for federal mineral production, including compensating states and the public for mineral production externalities, providing revenue to the federal government, and incentivizing certain types of production.

In 1970, the congressionally established bipartisan Public Land Law Review Commission recommended that all federal lands be retained in federal ownership unless disposal to private parties would achieve a greater benefit and provide equitable compensation. In establishing guidelines for public land management, the Commission stated, "[t]he end result, of course, is to achieve the maximum benefit for the general public ...."112

The Federal Land Policy and Management Act of 1976 requires that the United States "receive fair market value of the use of the public lands and their resources unless otherwise provided for by statute." ${ }^{113}$ The Federal Coal Leasing Amendments Act of 1976 likewise specifies that no bid may be accepted which is less than "the fair market value, as determined by the Secretary, of the coal subject to the lease." 114 The term "fair market value" is not defined in either

110. Federal Coal Leasing: Hearing on S. 3528 Before the Subcomm. On Mines and Mining of the H. Comm. on Interior and Insular Affairs, 93 Cong. 60 (1974), HRG-1974-IIA-0082 (statement of Jack O. Horton, Assistant Secretary, Land and Water Resources, Department of the Interior) [hereinafter Hearing on S. 3528].

111. For instance, primary responsibility for environmental protection began to shift from the states to the federal government with passage of the National Environmental Policy Act in 1969 and expansion of the Clean Air Act in 1970, among other federal statutes. See National Environmental Policy Act, Pub. L. No. 91-190, 83 Stat. 852 (1970); Clean Air Act Extension of 1970, Pub. L. No. 91-604, 84 Stat. 1676 (1970).

112. Public Land Law Review Commission, One Third of the Nation's Land: A Report to the President And to the Congress 1, 38 (1970).

113. Federal Land Policy and Management Act, 43 U.S.C. § 1701(a)(9) (2012).

114. Federal Coal Leasing Amendments Act of 1975, Pub. L. No. 94-377, 90 Stat. 1083, 1087 
statute. In 1982-the last time that Interior convened a working group to comprehensively review its fair market value procedures - the task force determined that "fair market value" was not merely the value of the resource discovered or produced, but the value of "the right" to explore and, if there is a discovery, to develop and produce the energy resource. ${ }^{115}$ Indeed, the Federal Land Policy and Management Act refers to the value of using the lands, and not solely to the value of the resources.

Central to the question of how royalties interact with externalities, the legislative history of both the Federal Land Policy and Management and the Federal Coal Leasing Amendments Act of 1976 reflects a concern that states be paid a greater share of federal royalties to account for social and environmental externalities incurred by resource production. Congressional testimony leading up to the passage of the Federal Land Policy and Management Act in 1976 reveals support for revenue sharing provisions that would direct a portion of revenue from federal fossil fuel production to the states where production occurs in order to "help county government[s] cope with energy development impact problems." 116

In considering a bill leading up to passage of the Federal Coal Leasing Amendments Act of 1976, which would direct an additional 12.5 percent of royalty revenues to states with federal leases within their borders (in addition to the 37.5 percent they already received at that time), the Committee on Interior and Insular Affairs stated, "[w]hen an area is newly opened to large scale mining, local governmental entities must assume the responsibility of providing public services needed for new communities, including schools, roads, hospitals, sewers, police protection, and other public facilities, as well as adequate local planning for the development of the community." 117 The legislative history also reflects concern as to "the waste of valuable resources, and the creation of severe environmental impacts." 118

(1976), codified as amended at 30 U.S.C. $\S 181$ et seq.

115. U.S. Gov'T ACCOUNTABILITY OFFICE, No. GAO-14-140, COAL LEASING: BLM COULD ENhance APPRAisal Process, More ExPlicitly CONSIDER COAL EXPORTS, AND PROVIDE MORE PUBLIC INFORMATION 3 (Dec. 2013), http://www.gao.gov/assets/660/659801.pdf.

116. Bills to Provide for the Management, Protection, and Development of the National Resource Lands, and for Other Purposes: Hearing on S. 1507 and S. 1292 Before the Subcomm. on Env't. and Land Res. of the S. Comm. on Interior and Insular Affairs, 94th Cong. 1 (1975), HRG1975-IIA-0120 (statement of James Evans, Legislative Rep., National Association of Counties).

117. H.R. Rep. 94-681, 38, 1976 U.S.C.C.A.N. 1943, 1975 WL 12515 (Leg. Hist.).

118. Id. at 20 . 
The Federal Coal Leasing Amendments Act increased the state share of revenue from federal coal royalties, provided that the state share be used by "giving priority to those subdivisions of the State socially or economically impacted by development of minerals leased under this chapter, for (i) planning, (ii) construction and maintenance of public facilities, and (iii) provision of public service ...."119 Thus, the Act directly links receipt of mineral production revenues to compensation for the social and environmental costs of mineral production.

Furthermore, coastal states and their congressional representatives have repeatedly advocated for a greater share of offshore oil and natural gas revenue due to significant potential impacts from these activities on coastal infrastructure and the environment. ${ }^{120}$ According to coastal states, these revenues are needed to mitigate environmental impacts and to maintain the necessary support structure for the offshore oil and gas industry. ${ }^{121}$ In addition, the Gulf of Mexico Energy Security Act of 2006 directs coastal states to use their share of royalty payments from offshore drilling for "the purposes of coastal protection, including conservation, coastal restoration, hurricane protection, and infrastructure directly affected by coastal wetland losses," and "[m]itigation of damage to fish, wildlife,

119. 30 U.S.C. $\$ 191($ a) (2012).

120. See Congressional Research SERVICE, No. R40645, U. S. OFFshore Oil AND GAS RESOURCES: PROSPECTS AND PROCESSES 19 (April 26, 2010), http://fpc.state.gov/documents/ organization/142736.pdf; see also Senate Hearing 113-122, Revenue Sharing Hearing before the Committee on Energy and Natural Resources, United States Senate, $113^{\text {th }}$ Congress, 1st Session to Consider S. 1273, The Fair Act of 2013 (July 2013), http://www.gpo.gov/fdsys/pkg/CHRG113shrg85874/html/CHRG-113shrg85874.htm (stating, inter alia, "[r]evenue sharing is vital for these [coastal] areas to adequately respond to all sorts of impacts associated with enormous influxes of people and equipment;" "[s]tates and communities will have less incentive to support this development if they're expected to shoulder risks and absorb impacts with no opportunity for revenue sharing;" "there are also cumulative impacts of offshore energy development such as habitat degradation and coastal erosion that are typically not mitigated at the project level, and it is important for states to address these impacts. Therefore, a significant portion of a state's revenue share should be directed to addressing those unmitigated cumulative impacts, including through coastal protection and restoration and investments in natural infrastructure such as forested wetlands, marshes, oyster reefs, barrier islands, and dune systems.").

121. Id. Of course, to the extent that states receive a greater proportion of the royalty as compensation for social, environmental, or economic impacts, the federal government will receive less unless the royalty rate is increased. Rather than reduce the federal government's share of the royalty simply because some externalities are borne by the states, Interior could-and should, from a welfare-maximizing perspective-increase the royalty rate in order to shift more of the externality costs onto fossil fuel producers and arrive at a more socially optimal royalty rate. See Jayni Foley Hein, Federal Lands and Fossil Fuels: Maximizing Social Welfare in Federal Energy Leasing, 42 HARV. ENVTL. L. REV. _ (forthcoming, Feb. 2018) (on file with author). 
or natural resources," among other delineated uses. ${ }^{122}$ Moreover, the federal Land and Water Conservation Fund, established in 1965, uses federal offshore oil and gas revenues to build and maintain public parks and protect open space across the country. ${ }^{123}$

Congressional efforts to modernize hardrock mining law also link royalties to compensation for negative externalities. Pursuant to the General Mining Law of 1872, one of the last remaining vestiges of the public land giveaways, companies can mine hardrock minerals on federal land without paying any royalties. ${ }^{124}$ The Hardrock Mining and Reclamation Act of 2007 would have imposed a royalty of 4 percent of gross revenues on existing mining and 8 percent on new mining operations. ${ }^{125}$ Seventy percent of the royalty revenue would have been directed to a cleanup fund for past abandoned mining operations, and 30 percent to affected communities. ${ }^{126}$ Similarly, the Hardrock Mining and Reclamation Act of 2009 would have directed the Secretary of the Interior to establish a royalty rate of between 8 and 15 percent of the value of mineral production from new mines on federal lands, with royalties and reclamation taxes used to reclaim abandoned hardrock mines. ${ }^{127}$ Neither bill was passed into law.

Finally, a recent federal regulatory effort aimed at reducing externalities from oil and natural gas production also recognized that royalty payments can be employed as policy levers. The Bureau of Land Management's 2016 final rule requiring methane emission reductions for oil and gas producers on federal lands exempts captured methane, the majority of which comes from natural gas, from royalties owed to the federal government. ${ }^{128}$ This royalty-free natural gas can be analogized to the "fair use" exemption from royalties in another familiar field, copyright law. ${ }^{129}$ In both contexts, policymakers

122. See 30 C.F.R $\$ 519.410(\mathrm{a})(2)(2014)$.

123. See 54 U.S.C. $\$ \S 200302,200305$ (2012).

124. The General Mining Law of 1872 , codified as amended at 30 U.S.C. $\$ \S 22-54$ (2012).

125. Hardrock Mining and Reclamation Act of 2007, H.R. 2262, 110th Cong. (2007).

126. Id.

127. Hardrock Mining and Reclamation Act of 2009, H.R. 699, 111th Cong. (2009)

128. See Bureau of Land Management, Waste Prevention, Production Subject to Royalties, and Resource Conservation, 81 Fed. Reg. 83008, 83043 (Nov. 18, 2016) (stating, "this section sets forth the general rule that royalty is not due on oil or gas that is produced from a lease or communitized area and used for operations and production purposes (including placing oil or gas in marketable condition) on the same lease or communitized area without being removed from the lease or communitized area.").

129. In the Copyright Act of 1976, Congress codified the fair use doctrine, which developed in the courts as an "equitable rule of reason which permits courts to avoid rigid application of the copyright statute when, on occasion, it would stifle the very creativity which that law is designed 
established a royalty-free "fair use" in order to advance the societal interest by, for example, incentivizing actions with positive externalities like capturing methane for local reuse at well sites, or using copyrighted material for educational purposes. ${ }^{130}$

Interior has also adjusted royalty rates for other purposes, including incentivizing certain types of resource production and capturing more value for the federal government. Surface coal produced has long been subject to a 12.5 percent federal royalty, while underground coal has been set at 8 percent. ${ }^{131}$ The main reason provided in the legislative history for giving Interior discretion to treat royalty rates for surface mining and underground mining differently was the perception that underground mining was more difficult and would produce less valuable coal. ${ }^{132}$

Finally, Interior raised the offshore oil and gas royalty rate in 2007 in response to a number of factors, including increased oil and gas prices, technological improvements that made exploration and production more efficient, and the competitive market for leases. ${ }^{133}$ Former Interior Secretary Ken Salazar said that increasing the offshore rate was necessary to ensure that "the American taxpayer is getting a fair return for the oil and gas that the American people own;" he also pointed to higher state onshore rates for oil and gas as a possible

to foster." See Copyright Act of 1976, Pub. L. No. 94 553, 90 Stat. 2541 (1976); Stewart v. Abend, 495 U.S. 207, 236 (1990) (internal quotes omitted) (emphasis added); see also Campbell v. AcuffRose Music, Inc., 510 U.S. 569, 575 (1994). Fair use provides a defense for infringing copyright uses which are permissible because their overall value to society outweighs the copyright owner's interest in enforcing its property boundaries. In other words, Congress made a policy judgment to set the "royalty rate" at zero for some uses of copyrighted material.

130. See, e.g., Manal Z. Khalil, The Applicability of the Fair Use Defense to Commercial Advertising: Eliminating Unfounded Limitations, 61 FORDHAM L. REV. 661, 661-62 (1992) (arguing that the fair use doctrine "acknowledges the social desirability of permitting others to build upon copyrighted works"); Simone A. Rose, On Purple Pills, Stem Cells, and Other Market Failures: A Case for A Limited Compulsory Licensing Scheme for Patent Property, 48 How. L. J. 579, 610-11 (2005) (arguing that "the strongest case for royalty-free fair use is the large number of positive externalities that are created through the use of creative/copyrightable subject matter").

131. 43 C.F.R. § 3473.3-2(a)(2) (2014); see 55 Fed. Reg. 2653-01 (Jan. 26, 1990).

132. See Hearing on S. 3528, supra note 110, at 62 ("You could certainly logically expect to have much less [sic] amounts bid in a competitive sale for deep coal if you had the same royalty for surface coal and deep coal."); see also COMPTROLLER GENERAL, IMPROVEMENTS NEEDED IN Administration of Federal CoAL-Leasing Program 1100 (1972) ("[H]e also might produce much less if he had per ton a higher royalty payment, so he might produce only the richest coal and not go into the less rich coal because of the higher royalty figure.").

133. U.S. Government ACCOUntability OfFICE, No. GAO-14-50, OIL And GAS Resources: ACTIONS NEEDED FOR INTERIOR TO BETTER ENSURE A FAIR RETURN 13-14 (Dec. 2013), http://www.gao.gov/assets/660/659515.pdf. 
justification for raising the onshore federal rate for oil and gas. ${ }^{134}$

Overall, the legislative history of congressional laws concerning the extraction of coal and other mineral resources demonstrates that leasing policies and royalty rates have been used pragmatically, reflecting policy concerns and concepts of compensation and fairness, including earning "fair market value." ${ }^{35}$ Adjusting state or federal royalty rates to meet valid policy goals, like reducing environmental externalities, would be in line with the U.S. government's long history of setting the terms and conditions of leasing its land for mineral extraction to reflect policy priorities.

\section{E. LESSONS FROM PRIVATE ROYALTIES}

So far, common law history, economic theory, and U.S. legislative history have underscored the appropriateness of federal and state governments acting as landowners and, in the interests of their respective citizens, adjusting mineral royalty rates to enhance public welfare. In this endeavor, private royalty rates and mineral resource leases might appear to be less relevant. In reality, however, these private decisions are influenced by similar factors, including expected economic rent, characteristics of the resource, competition for leases, and externalities that may affect the leaseholder, such as noise and pollution. ${ }^{136}$ Examining the factors that private parties consider when attempting to maximize their self-interest further underscores the validity of similar factors that the government may consider in setting royalties to advance societal goals.

Outside of any required state minimum, the exact value of a royalty rate can be negotiated between the mineral owner and the production company. The rates therefore vary and often depend on the

134. Hon. Ken Salazar, Secretary of the Interior, Interior, Environment, and Related Agencies Appropriations for 2013, Testimony before the House Committee on Appropriations, Subcommittee on Interior, Environment, and Related Agencies (Feb. 16, 2012), pp. 46-47, https://www.gpo.gov/fdsys/pkg/CHRG-112hhrg74739/pdf/CHRG-112hhrg74739.pdf ("The underlying principle is we are mandated by statute, mandated by fairness to make sure the American taxpayer is getting a fair return for the assets the American people own.").

135. See Federal Land Policy and Management Act, 43 U.S.C. § 1701(a)(9) (2012) (stating that it is policy that "the United States receive fair market value of the use of public lands and their resources unless otherwise provided for by statute").

136. See Colorado Oil \& Gas Assoc., The Basics: Mineral Rights, Royalties \& SURFACE USE AGREEMENTS (2013), http://www.coga.org/wpcontent/uploads/2015/09 /3Basics_MineralRights.pdf; Christopher Timmins \& Ashley Vissing, Shale Gas Leases: Is Bargaining Efficient and What Are the Implications for Homeowners if it is Not? (Dept. of Econ., Duke Univ., Working Paper, 2014), http://public.econ.duke.edu/ timmins/ Timmins_Vissing_11_15.pdf. 
negotiation power and skills of each party. Negotiation power, in turn, depends on how many acres of resource the mineral owner owns, how close the land is to "proven production," and how many other companies are competing for the specific lease. ${ }^{137}$ As expected, the owner of "a large tract next to a newly discovered field with numerous oil companies vying for the lease" would possess a significant amount of negotiation power ${ }^{138}$ and could negotiate a high royalty rate for the lease. Economists Christopher Timmins and Ashley Vissing have found that demographic factors are also associated with negotiation power, with high-income mineral owners able to negotiate higher royalty rates. ${ }^{139}$

In negotiating the substance of these private leases, the parties often take into account pollution, surface disruptions, and other externalities. For example, mineral owners, in addition to negotiating the royalty rate, can negotiate lease terms such as environmental clauses that encourage the use of safeguards to prevent contamination of soil and water, and noise clauses that require the use of mufflers with loud equipment. ${ }^{140}$ And in cases when mineral rights and surface rights are held separately (commonly referred to as a split-estate), the surface owner can negotiate compensation for protection from "unreasonable encroachment and damage" to the surface. ${ }^{141}$ One 1979 commentator urged that "[l]andowner-lessors should provide for escalating royalty payments according to the type of mining method used" to account for differences in waste production. ${ }^{142}$

\section{F. CONCLUSION}

Royalties have several commonly accepted justifications, including sharing in economic rent, compensating the owner for removal of a nonrenewable resource, and compensating the owner for negative externalities associated with production of the resource. While the externality justification appears much more frequently in

137. Judon Fambrough, REAL EstATE CENTER, TEX. A\&M UnIV., Hints On NEGOtiAting AN OIL \& GAS LEASE 3 (2015) [hereinafter Hints], https://assets.recenter.tamu.edu/ documents/articles/229.pdf.

138. Id.

139. Timmins \& Vissing, supra note 138.

140. Id. at 72 .

141. ANTHONy ANDREWS, UnCONVENTIONAL GAS Shales: DeVElopment, TECHNOLOGY, AND POLICY Issues 27 (2010).

142. Laurence W. Hancock, Note, Preventive Law and the Negotiating and Drafting of Coal Leases after the Surface Mining Control and Reclamation Act of 1977, 81 W. VA. L. REV. 733, 74647 (1979). 
recent economic literature and legislative history, royalties have been used as a policy lever to promote social welfare for centuries. Historical uses, accepted economic justifications, legislative history, and examples of royalty use by private actors all support the determination that it would be appropriate for federal and state governments to increase fossil fuel royalty rates to account for externality costs. Indeed, doing so would be an expedient and potentially lucrative way to align natural resources leasing with greenhouse gas reduction goals, even as other mechanisms to address climate change appear infeasible in the current political environment. 